\title{
THE BICS - ADVANCED METHOD OF THE ELECTRONIC SHIP REPORTING FOR THE RIS CENTRE
}

\begin{abstract}
The article presents principles of transmission and processing of the data in electronic reporting of river ships used in inland navigation. The new standard of electronic reporting of ships was shown - system Barge Information and Communication System (BICS). Results and analysis of surveys of real duplex transmission of data in BICS system for purpose of RIS Centre were presented.
\end{abstract}

\section{Keywords:}

River Information Services, Electronic Ship Reporting, processing and navigational data transmission.

\section{INTRODUCTION}

Shipping of goods within European Union have been increased systematically. During last few years it has been increased by $32 \%$ and according to forecasts it could increase still $50 \%$ by 2030 year [http://www.rijkswaterstaat.nl].

In Europe about $40 \%$ of trade is conducted by sea [Sanaba, 2009]. European Commission is willing to increase this percentage and move as much as possible transported cargoes from road (45\%) to sea/water transport. This concept is known as Short Sea Shipping and was initiated by the recommendation of the Maritime Industry Forum. Inland Shipping is prolonged part of such approach. To ensure sustainable optimization and development of transport with 
regard to safety and environmental protection work should follow together with collaboration in many fields of transport. The European Union possess over $35000 \mathrm{~km}$ of canals and rivers that connect major cities and industrialized areas of the European countries. The main European network of inland waterways is consisted of rivers Danube, Rhine and adjacent waterways. The fleet travelling just on the Rhine waterway can be estimated at about 6900 vessels, representing a transport capacity of 10 million tonnes, of which 1200 are pushed barges, 4400 motor cargo vessels and 1300 tankers [http://www.bics.nl]. Despite this, there is a number of tributaries and canals that connect smaller towns and industrial centres. A considerable number of ports along the network of inland waterways provide access to connection with other modes of transport.

Inland shipping has great potential to offer and can play an important role in the development of whole transport. Inland waterways are seen as a reliable, economical and environmentally friendly. They are assumed by the European Union as the main means of transport in the European modal transport system.

The development of transport requires introduction of new information technologies and solutions. It refers to recording, monitoring and distribution of safety information and implementation of available IT technologies in transport. One of such technology is River Information System (RIS).

RIS was developed to improve security and logistics in inland shipping. It is a system of information technology (IT) aiming to optimize the processes of communication management of transport in inland waterways. It aims also to increase the speed of data transmission between river ships being on the way and the land stations in real time and in advance [http://www.rijkswaterstaat.nl].

The system aims to enhance the exchange of information between users and system operators. European directive (EC/2005/44) from 2005 provides the minimum requirements describing trans-border compatibility of RIS systems. International guidelines for RIS are constantly being developed to harmonize the existing standards for particular river information systems and services within the European Union [http://www.rijkswaterstaat.nl].

Many institutions and experts associated with the RIS in inland navigation representing such parties like government bodies or research institutes are very interested in the optimization and standardization of various information services such as radio communication, Internet, Inland Electronic Chart Display and Information Services (ECDIS) which consists particular parts of the RIS system. 
The main objective of RIS is to improve the safety of navigation on the inland waterway: rivers, canals, ports etc. by obtaining the local and regional traffic information and by utilizing it for the purpose of efficient monitoring and management of traffic. It helps to increase the efficiency of inland waterway transport by providing the exchange of information between ships, locks, bridges, ports and terminals. In addition by providing information about the condition of the fairways, traffic and transport much more efficient utilization of inland waterways could be achieved and reduction of exhaust emission.

RIS area is formally described as an area where the service of River Information System is provided. It may comprise the inland waterways in a geographical river basin, both in the territory of one or several countries (eg. in a situation where inland waterway forms the border between two countries).

\section{THE ELECTRONIC SHIP REPORTING IN INLAND NAVIGATION-FUNCTIONAL REQUIREMENTS}

Traffic management on the fairway is entrusted to a specially appointed administrations which task is to ensure optimal use of infrastructure and safe navigation. This includes the traffic on the local inland waterways and the service of bridges, locks, berths [Smacki, 2015].

Management of the local traffic is achieved by the function of the Vessel Traffic Service (VTS). Vessel Traffic Services are created in areas where traffic flow, number of ships in narrow passages and the presence of navigational hazards make a high risk to navigation.

Centres of RIS/VTS are currently installed at critical points of the European waterway network and implemented by the competent administration authorities to improve the safety, efficiency, reliability of vessel traffic and to protect the environment. All required information is provided by coastal radar stations and AIS transponders (Automatic Identification System), which provide data such as the name of the ship and its current position. Additionally voyage reporting systems provide other information about the ship, such as a cargo or planned destination. These data delivered to the local traffic managers necessary information allowing them to inform and advise actors/ships in the area about the traffic and potentially dangerous situations. 
The Electronic Ship Reporting in inland navigation allows to improve the management of locks and bridges. These services support among other things, the calculation of the expected time of arrival (ETA) or requested time of arrival (RTA). This guarantee better planning of operational activities, which include: conflict-free passage, or shortening the waiting time in the queue. The information provided by lock and bridges operators allow fort the captains to adjust the speeds of their ships, which results in fuel economy and reduction of exhaust emission.

RIS enables monitoring of ships on inland waterway in real time and the conditions on the fairways. It enables more effective management of traffic and thus optimize the location of ships and personnel. Providing the information for terminals and locks about the expected time of arrival, the dimensions of the ship or cargo plan can significantly improve the operation of these entities and the use of their resources.

\section{DATA TRANSMISSION IN THE RIS SYSTEM}

Data transmission system RIS provides access to information about voyage details and shipped cargo by inland waterway vessels as well as swift and easy transfer of information from ships and land. For this purpose various methods of data transmission are used. We can list starting from Automatic Identification System for inland waterway ships (INLAND AIS), the Electronic Chart Display and Information System for inland navigation (Inland ECDIS) through GSM technology, Internet and VHF communication.

\section{Inland Automatic Identification System}

The International Maritime Organisation (IMO) in 2000 introduced for the purpose of shipping Automatic Identification System (AIS). All ships taking international voyages and affected by Chapter V of SOLAS convention (International Convention for the Safety of Life at Sea) are to be equipped with AIS (since the end of 2004). This technology was also implemented in the automatic identification of river ships and controlling of traffic on inland waterways: directive 2005/44/EC of the European Parliament and the Council from 7 of September 2005 on harmonized river information services (RIS) on inland waterways in the Community [Lisaj, 2009; http://www.ccr-zkr.org; http://www.eur-lex.europa.eu]. 
In particular, the function of marine AIS providing identification of ships in real time and the availability of worldwide standards and guidelines were especially helpful in securing the safety on the inland waterways. For this purpose it was necessary to develop technical specifications of AIS system for inland waterways which should be compatible with the maritime AIS system. Such compatibility allows the direct data exchange between seagoing and inland ships (receivers) in the zones of mixed traffic. AIS provides dynamic information, static information and details of voyage between equipped with this system ships and shore (land) stations. AIS equipment transmit at regular intervals information on the ship's identity, position, etc. Basing on this information other AIS receivers are able to identify and track ships automatically. This rise awareness on navigational situation, improves safety and facilitates VTS stations to control traffic.

\section{System of Electronic Chart Display and Information System for inland waterways}

Electronic Chart Display and Information System (ECDIS) was originally developed for maritime navigation but later it has been assumed for inland navigation. The ECDIS system for inland navigation was adjusted to distinct characteristics of inland waterways without amendments of the originally accepted ECDIS standards by the International Hydrographic Office (IHO). This approach was defined by the EU directive 2005/44/EC of the European Parliament and the Council from 7 of September 2005 on harmonized river information services (RIS) on inland waterways in the European Union. In this way it was possible to obtain compatibility between the maritime ECDIS and the system designed for navigation on inland waterways. It is important especially on the rivers estuaries where sea and river ships could navigate [CCNR, 2011; EC, 2007].

Inland ECDIS can be used in the information mode (just electronic chart without information about traffic) and navigation mode (radar picture overlaid on chart, AIS data displayed on chart).

Information Mode is based on an electronic catalogue used to display information about the waterway. However this mode is not intended to navigate the ship. When connected to a navigation sensor providing position information, the chart can be automatically adjusted in such a way that the position of own ship is set in a central position of the screen. It is also possible to display positions of other objects equipped with Inland AIS provided that own Inland ECDIS is connected to AIS receiver. 
The Navigation Mode means that ECDIS is used to conduct navigation of the ship with radar overlay on the chart. It is worth to mention that on river Rhine inland ECDIS fit to function of navigation mode is classified as radar equipment defined in the regulations concerning the minimum requirements, test conditions, installation and functional test applied to radar.

\section{European Standard ERI - BICS method}

Information about the ship, position, movement and cargo are important for all parties involved in transport operations, such as administrative authorities, operators of locks, emergency services, port operators, shippers etc. For this reason it was created Electronic Reporting System. The standards for this system in the inland waterways describe: the messages, data and codes used in the electronic report of ships for various RIS services. Reporting and transmission of electronic messages ensure to provide all necessary information in a timely manner and to a specific recipient. These messages provide fast shipping and transparent procedures with adequate control and simplified process of water transport [Lisaj, 2009].

The technical specifications define the structure of four messages for electronic ship reporting in inland navigation based on the structure of UN/EDIFACT and if necessary adapted for the purpose of inland navigation. Where national or international law requires electronic ship reporting in inland navigation applies these technical specifications. These are the following messages:

- ERINOT message with response and receipt confirmation; Electronic Reporting International Notification Message is a compulsory message for reporting details of voyage and cargo (dangerous cargoes on board or as well their absence) by the ships in inland waterways for the proper centres of jurisdiction or administration;

- dangerous cargo declaration;

- list of passengers and crew;

- message concerning stay at port.

Standard ERI and BICS software for electronic reporting capabilities and business contacts are commonly used and both fully meet the real needs of the authorities and commercial users. For instance, through project 'Paperless Sailing' realized in Antwerp and Rotterdam the possibility of the use of electronic ship reporting has been significantly increased. Through the policy registration data about traffic registered in IVS90 system transmitted by ships are adequately protected against unauthorized access. Data are not illegally used, shared or published. All data are stored for a limited period of 7 days. 


\section{The Barge Information and Communication System}

The Barge Information and Communication System (BICS) is an electronic system, which was founded by the Ministry of Transport, Public Works and Water Management (Rijkswaterstaat) in Holland (since 2010 Ministry of Infrastructure and the Environment.), which provides access to information about the cargos and river ship being engaged in inland navigation. It ensures prompt transfer of information from river ships to land and vice versa (via internet or mobile GSM to the various port authorities and VTS officers) [Sanaba, 2009; http://www.imo.org].

BICS system consists of the following parts [Sanaba, 2009]:

- BICS application where user can enter data and report voyage and cargo information;

- BICS communication module, which processes the messages;

- module BASWIN (Berekening en Analyse Seinvoering) which calculates and analyses of signals;

- module BOS - receives and displays voyage messages and water levels;

- additional BICS application (used while crossing the borders of countries outside the European Union) consisting of:

- custom declaration of goods,

- list of crew members and list of passengers.

BICS system allows to obtain information from external navigation sources like radar, AIS or electronic chart. This allows operators to control traffic on the actual display and obtain current information about position of reporting ship/barge (Fig. 1).

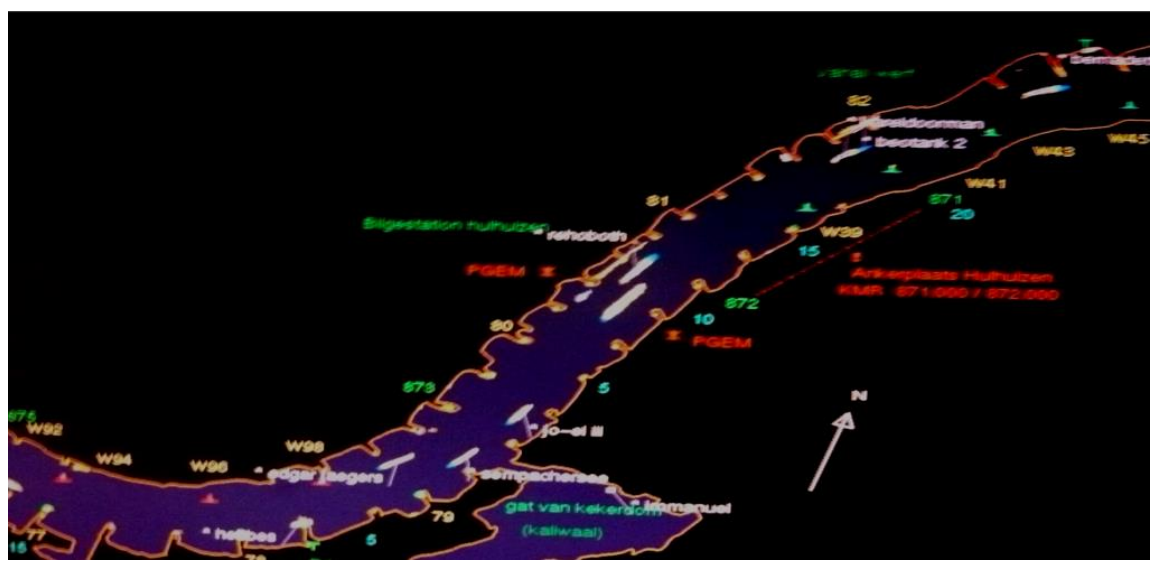

Fig. 1. The display of electronic chart in RIS centre with sector of river Wall in Nijmegen area 
The operator at RIS centre can display all sectors and locks covered by BICS system. It covers all Dutch canals and rivers. Operator can obtain the list of all ships/barges being in particular sector what allows early prediction the movement of the ship/barge and to plan and prepare advices for ship's operators.

An example of advance panning can be queue of ships/barges intended to pass through the lock. Officer at traffic control basing on the information obtained from BICS system may advice some ships to reduce their speed or delay the ship's departure from the berth. It helps to maintain a continuous flow of traffic through the lock and as well can contribute to reduce fuel consumption and protect environment by decreasing exhaust emissions.

\section{Improving reliability of River Information System}

Positioning of own river ship during passage or maneuvering on inland waterway is performed by visual/radar observation what is known to methods of terrestrial navigation in coastal navigation. Positioning of other ships in onboard information system (ECDIS) or in River Information Systems is based on GNSS observations (position received by AIS transponder), radar observations or CCTV pictures analysis. On the waterways distances between river ship and edge of the waterway or between other ships during passing/overtaking are very small. Due to that fact and safety reasons ships in the information systems should be presented not as just points or symbols but as cartographic objects. It should be an contour commensurate with real dimensions of the ship [Uriasz, 2011] and additionally consideration should be given to the accuracy of spatial position determined in reference to the location of the antenna. Geometry of the contour of ship presented in the information system may further depend on ships maneuvering capability (stopping distance, circulation parameters etc.), dynamical parameters (speed, rate of turn, etc.) and the surrounding environment (Fig. 2).

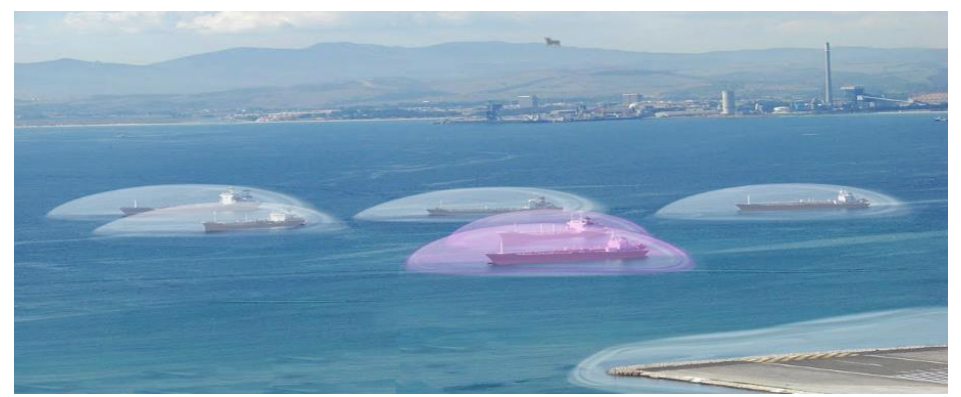

Fig. 2. The visualization of ships in motion in Maritime Volumetric Navigation System, implemented under the EU Ariadne project 
Such visualization of river ships in the information systems could significantly reduce human error in avoidance of collision, manoeuvring and navigation in channels, crossings, port traffic, congested approaches to locks, passing bridges, etc. It may increase the reliability of River Information System.

\section{TRANSMISSION OF DATA IN THE BICS SYSTEM}

Administrative authorities of the EU member states engaged in inland navigation require adequate information about traffic. It enable to manage traffic on waterways, ensure safety and to estimate if any dangerous cargos pose a direct threat to people or the environment. The traffic information has been transmitted orally and/or by fax or similar media recently to the port managers, locks, bridges and other bodies of administration [CCNR, 2011; http://www.bics.nl]. The BICS system enables to deliver information in a faster, more reliable and confidential way. With regard to the latter, confidential information is highly sensitive in business relationships. The obligation of the user is just to enter the data containing the names of the ports of loading and discharging, cargo specification, marking and accurate names of loaded dangerous substances (allowed to be transported by inland waterways). Integrity functions in the BICS system eliminate misunderstandings resulting from incorrect entries and thus make the system more reliable.

Messages EDI (Electronic Data Interchange) forwarded to the authorities by the masters can be obtained by BICS system (Fig. 3). The BICS system allows to exchange detailed information about the cargo and planned loading and discharging points during the voyage. These data are transmitted to the various bodies of inland waterway transport and port authorities. The BICS has been in operation since 1996. System is in use in following countries: Austria, Belgium, France, Germany, Holland, Luxembourg and Switzerland. On river Rhine standards of communication, requirements for equipment, regulations, obligations, etc. are regulated by Central Commission for Navigation of the Rhine [http://www.bics.nl]. 


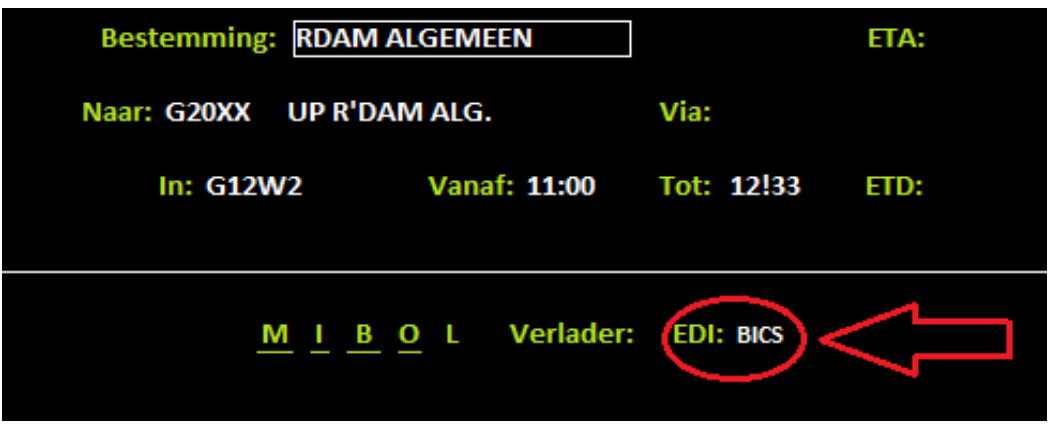

Fig. 3. Part of the report delivered to the RIS center with information about the used method of electronic data exchange via the BICS [own study on the basis of information obtained in 'Verkeerscentrale Nijmegen' — Smacki, 2015]

The default data of the ship: name, dimensions, the European number, owner are entered into the system at the time of its delivery. Therefore user enters only the variable data for each voyage like: port of departure, port of call, quantity and type of cargo, draft, number of persons on board (Fig. 4).

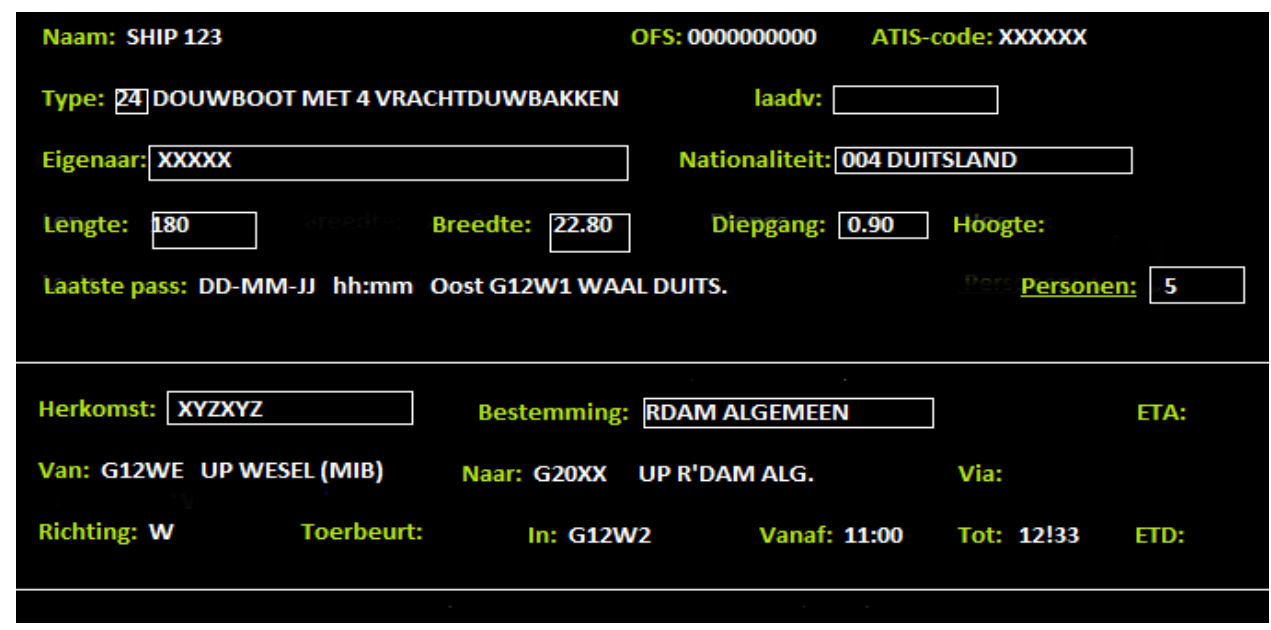

Fig. 4. Report of the ship and its details of voyage received by the RIS/VTS centre [own study basing on information received from 'Verkeerscentrale Nijmegen' in Holland - Smacki, 2015]

An important option in the described system, it is also possibility to extract the interesting types of ships (Fig. 5). 


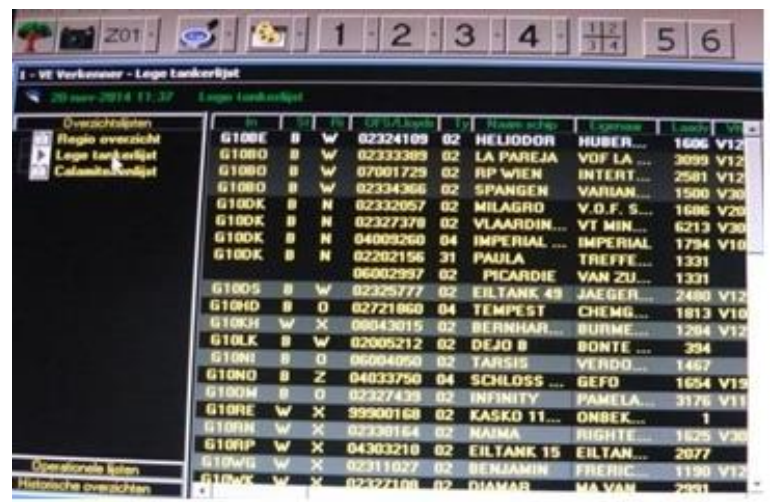

Fig. 5. Report of empty river tanker barges [own study basing on information received from 'Verkeerscentrale Nijmegen' — Smacki, 2015]

In practice it could be used in during emergency situation like groundings or collisions which could lead to loss of life, cargo, ship. In every emergency situation operator of vessel traffic service could obtain information about available resources (ships/barges) in the vicinity able to take over/transfer persons/cargo/ fuel from damaged ships. In such cases response time is one of the main factor of effectiveness of rescue operations.

\section{CONCLUSIONS}

In 2005 the European Parliament and the European Council adopted a directive on harmonized the River Information Services on inland waterways in the European Community, which applies to all inland waterways of class IV and higher and ports.

The development of RIS systems, combined with cost-effective and environmentally friendly transport, increases the safety of inland navigation and improves decision-making process of masters.

Increasing traffic on inland waterway urges development and introduction of advanced systems and technologies allowing effective management of transport.

In the European Union unified RIS standards have been assumed. An example of information system applied for inland waterway shipping is a Dutch BICS system. It provide information services, facilitates the flow of information, 
and represents a unified communication system. BICS system improves safety of navigation by rising knowledge and awareness about current traffic on inland waterways. It is a system of information technology optimizing the processes of communication and transport in inland waterways.

The main elements affecting the operation of the system are transmitted data. Information gathered and transmitted by RIS improves safety of navigation on inland waterways, helps to perform duties of masters and traffic controllers.

\section{REFERENCES}

[1] Central Commission for the Navigation of the Rhine (CCNR), Inland ECDIS \& Electronic Ship Reporting in Inland Navigation, 2011.

[2] European Commission, EU directive (EC) No. 414/2007 of 13.03.2007: Guidelines for planning, implementation and operation of River Information Services, Official Journal Commission, 2007.

[3] Lisaj A., Electronic reporting of ships in the RIS system, TRANSNAV-2009, Gdynia 2009.

[4] Smacki A., Survey and analysis of duplex communication of data in RIS system, [in Polish], Maritime University in Szczecin, Szczecin 2015.

[5] Sanaba M., Short Sea Shipping efficiency analysis considering high speed craft as an alternative to road transport in SW Europe, Phd Thesis, Univeristat Politecnica de Catalunya, 2009.

[6] Uriasz J., Determination of ship's safe navigation lane in the navigational information system, 'Annual of Navigation', Gdynia 2011.

[7] http://www.bics.nl [access 10.09.2016].

[8] http://www.ccr-zkr.org [access 10.09.2016].

[9] http://www.eur-lex.europa.eu [access 10.09.2016].

[10] http://www.imo.org [access 10.09.2016].

[11] http://www.rijkswaterstaat.nl [access 10.09.2016].

[12] http://www.ris.eu [access 10.09.2016].

Received September 2016

Reviewed November 2017

Published 07.12.1017 


\section{ANDRZEJ LISAJ}

Maritime University of Szczecin

Wały Chrobrego 1-2 Str., 70-500 Szczecin, Poland

e-mail: a.lisaj@am.szczecin.pl

\section{ANDRZEJ SMACKI}

e-mail: andrzej.smacki@wp.pl

\section{JANUSZ URIASZ}

Maritime University of Szczecin

Wały Chrobrego 1-2 Str., 70-500 Szczecin, Poland

e-mail: j.uriasz@am.szczecin.pl

\section{STRESZCZENIE}

W artykule przedstawiono zasady transmisji i przetwarzania danych przez statki rzeczne w śródlądowych systemach nadzoru nawigacji. Omówiono nowy standard raportów znany pod nazwą Barge Information and Communication System (BICS). Zaprezentowano też wyniki analiz i badań efektywności łączności dupleksowej w warunkach rzeczywistych przedstawianego standardu BICS w aspekcie systemu nadzoru ruchu na rzece. 